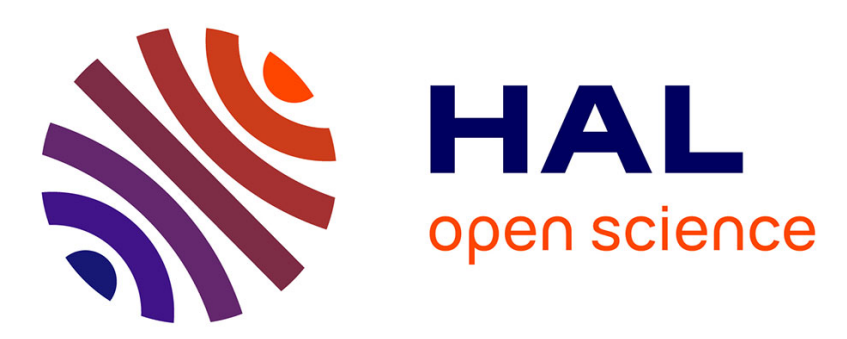

\title{
A Consideration of the Code of Computer Music as Writing, and Some Thinking on Analytical Theories \\ Maxence Larrieu
}

\section{To cite this version:}

Maxence Larrieu. A Consideration of the Code of Computer Music as Writing, and Some Thinking on Analytical Theories. Organised Sound, 2019, 24 (3), pp.319-328. 10.1017/S1355771819000384 . hal-02386818

\section{HAL Id: hal-02386818 https://hal.science/hal-02386818}

Submitted on 17 Dec 2019

HAL is a multi-disciplinary open access archive for the deposit and dissemination of scientific research documents, whether they are published or not. The documents may come from teaching and research institutions in France or abroad, or from public or private research centers.
L'archive ouverte pluridisciplinaire HAL, est destinée au dépôt et à la diffusion de documents scientifiques de niveau recherche, publiés ou non, émanant des établissements d'enseignement et de recherche français ou étrangers, des laboratoires publics ou privés. 


\title{
A Consideration of the Code of Computer Music as Writing, and Some Thinking on Analytical Theories
}

\author{
Maxence Larrieu, \\ LISAA, UPEM,77454 Marne-la-Vallée \\ maxence@larri.eu \\ orcid.org/0000-0002-1834-3007
}

\begin{abstract}
This article focuses on the analysis of computer music, that is, music which uses programming languages so that what the listener hears is the result of computer code. One key point in this article is that this music exists with some writing, i.e. the computer code. I note that this key point has not been addressed in the latest theories for analysing computer music. Indeed, we often see this music as part of the electroacoustic field, where the audio signal is essential, and where we usually read that those musics are non-written music. After an introduction on this topic, in the first section I will make a distinction between 'before the signal' and 'from the signal' to organise the theories to analyse electroacoustic music. In the third section, I will focus on computer music and I will show the historical difficulty in considering 'code' in musical analysis, mainly with an important exchange between two pioneers, (Stroppa 1984) and the answer of (Risset 2001). In the fourth section I will explain with Jean-Claude Risset and Horacio Vaggione the specificity of computer music; this music is written. Finally, I will look into a recent analysis theory, the Interactive Aural Analysis by Michael Clarke, which seems to fit with the latter specificity.
\end{abstract}

\section{INTRODUCTION}

My article deals with the analysis of computer music, and more precisely the one using at least one programming language, so that what the listener hears is the consequence of some computer codes ${ }^{1}$. This music is peculiar in that it does exist with a digital medium, which contains all the 'instructions' to be 'transformed into music'. Therefore, the medium of computer music has to be differentiated from the one of electroacoustic music. The former is made of 'code', which (i) contains some operations made by the composer and (ii) permits us to hear the work, whereas the latter is an audio signal, which allow us to hear the work. Considering this difference, one may wonder how this peculiar medium can be used to analyse music, which tools and theories can be helpful for the analyst?

The question of code in musical analysis is not new. One pioneer is certainly Marco Stroppa, an author whom we will consider in detail later in this article. Another key author

1 Therefore, computer music here is not restricted to a genre, it includes either 'live or tape' computer music, algorithmic or generative music, mixed and interactive music, and computer synthesis and treatment. 
is Jean-Claude Risset, who has shown that computer code should be considered as a key resource in computer music analysis:

It is only by integrating the musical and technical data that one can reach a structural description of the work which can make up for the lack of score.

(Risset 2001: 157), my translation.

Over the last twenty years following the article of Risset, more analysis of computer music based on computer code has become available. For example let's consider (Bonardi 2017) (Bergsland 2011) and (Clarke 2010). However, although there are some applications, I found there are not many theories which consider code, with all its richness, as Jean-Claude Risset pointed out. My article can be understood as a humble contribution to the analysis of computer music works based on their code. It is composed of the following four sections. In the first one I will present, with the help of a personal diagram, different theories for analysing electroacoustic music; in the second one I will shed light on the pioneering period where it was difficult to consider code of computer music to make analysis; in the third one, I will deal with the specificity of computer music; finally, in the last section I will discuss a recent analysis theory, the Interactive Aural Analysis by Michael Clarke, which seems to fit the specificity of computer music.

\section{ANALYSING COMPUTER MUSIC}

Since the middle of the twentieth century there have been a lot of theories to analyse electroacoustic music. In order to organise these theories, I suggest taking the following diagram as a starting point.

musical scores
drafts
sketches
working notes $\longrightarrow$ audio signal
files
codes
scripts
data
...

As can be seen the diagram is based on the materials used in analysis. It allows the reader to clearly distinguish two general directions in analysis. The first one uses mainly the audio signal of the work, it is the key object. It should be mentioned here that audio signal has to be understood as something which permits us to hear the work: samples used in composition, or signal in technological meaning ${ }^{2}$ are both excluded - here, audio signal is an object which allows us to hear the work. By contrast,

2 Indeed my definition go over the technological meaning: a signal without sound (e.g. very low/high frequency) is not considered here. 
the second direction in analysis can use a diversity of objects, and all of them are related to the composition and are situated 'before the signal'.

One advantage of this organisation is that it is highly legible. For example, Pierre (Couprie 2003)'s analysis of Trois rêves d'oiseau (1971) by François Bayle, is 'based on the audio signal', whereas John Chowning's Stria (1977), analysed by Matteo (Menegheni 2007) is 'before the signal', since it used essentially sketches of Music $\mathrm{N}^{3}$.

This difference is also present in a recent work made by Pierre Couprie. After presenting a synthesis of the main theories that have been developed for 'the composition, the interpretation or the musical analysis', the author shows two methods of analysis. The first is 'based on the perception of the audio support' and the second uses 'the creation support which has been made available by the composer' (Couprie 2016: 160).

Lastly, I have to notice that this distinction is relevant on a theoretical level, so that one can organise theories without ambiguity. Indeed, even if the analysis is realised 'before the signal', it is obvious that at one point the analysts have to listen to the music. For example, in the famous analysis made the $\mathrm{GRM}^{4}$ entitled L'envers d'une œuvre : 'de natura sonorum' de Bernard Parmegiani, which is made 'before the signal', one can read 'Our first object of study was, chronologically, De Natura, it was the music' (Mion, Nattiez, and Thomas $1982: 32$ ), my translation.

\subsection{Analysing 'from the signal'}

The analysis from the signal fits electroacoustic music. Indeed, without a traditional score, the first object which comes into contact with the work is the sound of the work, the audio signal.

Analyses from the signal include (i) analyses where the signal is only read, i.e. the signal is used as a tool to proceed in the listening of the work, and (ii) analyses where the audio signal is examined by technological means. Consequently, this way of analysing music gathers a lot of practices and theories which are still in evolution. For example, the recent three year project New multimedia Tools for Electroacoustic Music Analysis considers analysis from the signal: 'Our research is primarily listener-focused - the composer's intentions, methods and approaches may influence but not define the experience of the music' (Emmerson and Landy 2012: 2).

Thinking musical analysis only in the act of perception has needed intellectual efforts. For example, one can think of Schaeffer's catchphrase 'music is made to be heard' (Schaeffer 1952: 117). One way to explain it is to focus on 'the embryogenesis' of electroacoustic music: musique concrète of Pierre Schaeffer. As we know, this music was born with the famous phenomenological concept of écoute réduite: sound has to be perceived without taking into account the causality ; it must be perceived only in the act of perception. This concept leads to a new field in musical analysis, which can be seen as the research of means to analysing music only in the act of listening, i.e. without searching for something from the creation process (the poietic). This situation was not self-evident, as François Delalande points out in the introduction of his recent collection (Delalande 2013). After describing as a 'rich period' the moment when the

3 Music N refer to a family of programming languages which uses the scheme of Music V. See section 3.1 for one explanation of the Music V scheme ; (Mathews 1963: 555) for the historic presentation and (Manning 2004: 187) for a historical viewpoint.

4 Groupe de Recherches Musicales 
classical theories of musical analysis appeared - e.g. Generative Theory of Tonal Music (Lerdahl and Jackendoff 1983), Schenkerian model (Forte 1982) and Paradigmatic analysis (Ruwet 1972) - the author sees in the electroacoustic music 'a new paradigm [which] shows some disorder, if not revolution' (Delalande 2013: 7).

In this framework - no conventional notation ; with the concept of reduced listening ; and where listening is fundamental - the theoretical means of electroacoustic music analysis necessarily comes from the audio signal of the work :

The object to be analysed, that is to say a work or a given extract under its sound form, does have a certain materiality: it is a signal, fixed on a support, which becomes an acoustic wave. (Delalande 2013: 10), my translation.

My goal here was to show that those theories have something in common: all of them are based on audio signal. However, if we consider all the theories for analysing electroacoustic music from the signal, our latter diagram is no longer significant. Another step could be to clarify how the audio signal is used. For example, I can differentiate analysis where the signal is technically analysed (e.g. waveform, sonogram or sound descriptor), from the analysis where the signal is used just as a support for the listening. This is present in (Marty 2016), with a vertical dimension: at the bottom there is the sonogram and sound descriptors, and then, successively, the famous electroacoustic theories of typo-morphology (Chion 1994) and spectromorphology (Smalley 1986), and lastly music as a human experience, with the 'listening conduct' of François Delalande.

\subsection{Analysing 'before the signal'}

Even if there is no score as the musicologists knew from past centuries, it is possible to analyse electroacoustic works 'before the signal'. One historic example is the analysis made by the GRM (Mion, Thomas and Nattiez 1982). The documents used were an interview between the author and the composer, and secondly some sketches and listening scores made available by the composer at the time of the composition. In the following subtitles, I will give a preview of two theories for analysing 'before the signal', which are more related to computer music: genetic criticism applied to music and the faktura.

\subsubsection{Genetic criticism applied to music}

Genetic criticism applied to music is a main topic which is taking shape between philology and hermeneutics. Facing this density, my goal here is only to present the main idea, and then present the viewpoint of Laura Zattra. My point of view lies in a recent collective book, (Donin 2015) where genetic criticism is applied to music. Two key points can be found in the introduction. The first one is that genetic criticism is built with a main concept of writing, from which comes its 'love for the text', and the second one is that the theory is interested in the gestation of the artistic work. Of course, these two points are correlated: it is because of the real principle of writing let's say that it freezes the time in which it takes place - that the genetic criticism can trace back to the gestation of the work :

In suspending the time, by offering some tools to organise and hierarchise the contents, by allowing the possibility to go back, the re-reading, the 
repentance, the writing constitutes a cognitive technology particularly adapted to complex creation process. (Donin et al 2015 : 11), my translation.

So the genetic criticism applied to music is made with sketches coming from the composition. Of course traditionally those sketches were manuscripts, with musical notation, but nowadays, as we will see, it can also be computer code. Therefore, genetic criticism does not need to be restricted to traditional music. With a non trivial conceptual step, it can also be applied to computer music. However, possibly because of this step, the applications are not numerous ${ }^{5}$; one of the first authors is (Zattra 2015).

The conceptual step consists of seeing the act of writing within the computer, and in the same way conceiving the traces coming from the poietic process as 'text'.

\begin{abstract}
The computer music works are generally realised in wide research and production centres, and show, after analysis, a predilection for the idea of 'crafts' which is realised through the writing, an action characterised by the presence of texts, in the wider sense of the term. [Les œuvres sont en général réalisées dans de grands centre de recherche et production, et montrent, à l'analyse, une prédilection pour l'idée "d'artisanat" qui se réalise à travers l'écriture, une action caractérisée par la présence et l'élaboration de textes, au sens large du terme] (Zattra 2015: 213).
\end{abstract}

Indeed, to apply genetic criticism to computer music, the concept of text 'has to be widened' (ibid. 220). Then the computer is seen as a 'source for the study of the process/translation between the musical universe of the composer and the digital one'. '[This process] produces some "texts" which schematise and operationalize the compositional choices'(ibid. 220). For the analyst, those 'texts' allow to shed light on the compositional choices, and to describe the 'construction process of the work'. (ibid. 220).

\title{
1.2.2 The faktura
}

In 2003, M. Battier developed a new theory for analysing electroacoustic music, with some ideas inspired from Constructivism, a Russian artistic movement at the beginning of the twentieth century. The theory is described in an article entitled $A$ Constructivist approach to the analysis of electronic music and audio art - between instruments and faktura (Battier 2003). It is a well-known article and most of the analysis based on the study of the sound production technologies make reference to it, e.g. (Bonardi 2013), (Dufeu 2010) and (Baudoin 2007).

The faktura concept starts with a general idea: 'technology, artistic technique and aesthetic thoughts [are highly] intertwined' (Battier 2003: 251). Constructivism is used to focus on the interactions between technology, technique and style, which took place during the creative process.

The faktura works with another concept, inherited from Constructivism, the tectonic. This one allows to distinguish the artist action from the materials that existed at the time of the creation.

The theoretical effort of the Constructivist was aimed at defining the relation between the act of creation and its materials. (ibid. 251)

5 For example in (Zattra 2005) the author made an overview on the existing methods to analyse electroacoustic music, and in the 'Genetic analysis' subtitles, except of her own works, only (Lorrain 1980) appears. 
The definition of faktura relies on this distinction. It focuses on the moment when the artist - 'either a sculptor, painter, poet, musician or audio artist' (ibid. 251) - acts on this collection of materials : 'Faktura is the category with which an artist transforms materials' (ibid. 251). And of course this transformation is made with technology. The idea behind faktura is that once light has been brought on how the artist uses and transforms materials, the artist's style can then be described : 'in the Constructivist's approach, style becomes a topic which should be dealt with using a poietic method' (ibid. 254).

The music issues are tackled after dealing with the general definition of Constructivism. Battier's proposal is based on the sound-producing system and twowell known levels in musicology: the symbolic and signal ones - see (Malloch et al 2006) for example. First, the sound-production system has to be deeply understood, and then the link between this system and (i) the composition (symbolic domain) and (ii) the 'actual realisation' (signal domain) have to be enlightened. (Battier 2003: 252).

Finally, it should be said that Battier's faktura is not dedicated to computer music. Indeed the concept aims to grasp all the sound technology of the twentieth century, i.e. sound recording, electrical, electroacoustic, electronic and lastly digital sound (ibid. 252). In the same way, Battier didn't speak about electroacoustic music or computer music, but targeted a larger view, speaking of 'audio art'.

In this first section I have given a diagram which permits the organisation of theories to analyse electroaoustic music. Those theories can be situated 'before' or 'from the audio signal' of the work. Next, I have given two examples of theories which aim to analyse 'before the signal': genetic criticism applied to music, which focuses on the concept of text, and the faktura, with the notions of style and materials. In the next section I will focus on computer music and the possibility to make analysis 'before the signal'.

\section{ANALYSING COMPUTER MUSIC BEFORE THE SIGNAL}

To my knowledge, the question of analysing computer music 'before the signal' was treated for the first time in 1984 by Marco Stroppa (Stroppa 1984). Ironically, Stroppa's article points out the difficulties of analysing this music in a non aural way : it results from the impossibility for the author to analyse the famous work Songes (1979) by Jean-Claude Risset, for recording instrumental sounds, computer synthesis and treatments.

In this section, I present three points which highlight this difficulty.

\subsection{Code}

First of all, and even if it is tautological, we have to consider that computer music produces some 'coded traces' (Risset 2001: 16).

According to this, we can then put forward two other considerations. Coded traces:

- can only be read if the programming language is known;

- come from an activity of design; 
- so can be seen as the programmer's own reflection: computer music traces contain some strong idiosyncrasies.

This underlines the fact that reading coded traces is not easy. Firstly, one has to know, or even be a master in the programming language used - and those languages evolve with time - and secondly, these traces are idiosyncratic. Indeed we have to distinguish the reading of coded traces from that of natural language ${ }^{6}$.

This difficulty is present in Jean-Claude Risset's writings when he speaks of 'cryptic traces':

Even for someone who is familiar with the language, the MUSIC V scores are cryptic, the process are described in an almost atomic way. Risset in (Lorrain 1980 : preface), my translation.

To take full advantage of these somewhat cryptic traces, those who undertake the analysis must be enlightened specialist, often composers themselves. Risset in (Licata 2002 : xvii)

It is also present in an analysis made by Agostino Di Scipio on Contours (1982) by the same Risset. Di Scipio writes: 'I scrutinized many Music V code listings that the composer had written for this piece' (Di Scipio 2000: 2).

Lastly, this difficulty is glaringly present in (Stroppa 1984). One can think that Stroppa project of analysing Songes could have been accomplished if he had had, as Di Scipio did for Contours, the code of the work. Indeed, this is what (Risset 2001: 154) suggests. However, this would not work as at the time of writing (1983 - it is fundemental to notice that at that time the computer was not yet democratized) the 'cryptic traces' were seen by Stroppa as 'operational data', and were useless for musical analysis:

This is therefore linked to a specific machine and program. It is completely incomprehensible to most musicians, and directed simply towards specialists. (Stroppa 1984: 177)

\subsection{Tape music ?}

My second point concerns the words used to name this music. In the pioneering period, we used to refer to computer music as tape music. And obviously using the term tape, which refers to the magnetic tape on which audio signal is written, slows down, inevitably, the consideration of code.

For example this problem is present in (Stroppa 1984). Just after the introduction, he writes that 'To narrow the horizon further, I shall limit myself to consideration of tape music which has kept abreast of the evolution of thought in contemporary music' (ibid. 176). Then, in the second paragraph, which deals with the possibilities to analyse this music, the focus is now on computer music :

If we attempt to hold firm to these principles and apply them to computer music, we discover quite new problems and a new reality (ibid. 177)

6 Briefly one can notice that in the latter at least two words can be invented, whereas in the former all the variables names and the subroutines, for example, are invented 
When (Risset 2001) answers Stroppa, one key point he put forward is how we name this music. With Risset the issue is not about electronic music or tape music, but precisely, as the subtitle mentions 'musical works whose realisation involves computer' (my translation).

In a more astonishing way we can find this problem in (Lorrain 1980). Simply, the title of the document is 'Analysis of the tape of the work Inharmonique by Jean-Claude Risset' [Analyse de la bande magnétique de l'oeuvre de Jean-Claude Risset Inharmonique]. This is astonishing because if the work of Lorrain is historic and 'rare' as (Nucibella, Porcelluzia and Zattra 2005) pointed out, this is precisely because the medium used for the analysis is not the tape but the Music N score ... those very cryptic traces.

In the same way, we have to consider that the historic work of Lorrain was not meant to be an analysis. It is an Ircam report - which has never been published and is without pagination - ordered for teaching purpose, as Jean-Claude Risset said in the preface :

Denis Lorrain made this report at the request of Michel Decoust and for IRCAM internships for composers, but my experience with some similar documents (like my catalog of digital sound synthesis) reveals that they can be used in a broader scope. Risset in (Lorrain 1980: preface), my translation.

My comment does not impact the quality and the relevance of Lorrain's work, but it shows that in 1980, a musical analysis based on computer traces is not obvious; it shows the difficulty of an analysis based on computer music code.

\subsection{Ontology}

I suggest that the ontology of computer works can deeply explain this lack of consideration of code. Substantially, in this pioneering period code of computer music wasn't considered because no link was made between code itself and the existence of the work. Once again, this is significant in (Stroppa 1984: 177):

One of the principal characteristics of [computer music] is that it exists and is performed more or less exclusively on tape, without any effective visual representation.

Indeed, in this period of time it was hard to conceive code as something related to the existence of musical works. First of all, the musicological community has been used for centuries to consider one material object, the graphical score, as the centre of the existence of musical works. For example in the famous Sémiologie musicale et musicologie générale one can read :

What results from the composer's creative gesture, is, in Western tradition, the score ; what makes the work feasible and recognisable as an entity, is the score ; what allows it to cross the centuries is again the score. (Nattiez 1987: 99, my translation)

Secondly, at the time of Stroppa's article (8os), it should be said that code was not similar to the one of our digital age, it was low level (low abstraction) and some 
languages belonged to specific hardware - cf. (Wang 2008: 14) for example. Consequently, code was of short duration and quickly became obsolete.

\section{COMPUTER MUSIC CODE AS WRITING}

In the last section I have shown that computer music has something specific, which makes it difficult to fit inside the tape music appellation. I found that this specificity has been highlighted by two famous composers and researchers, Jean-Claude Risset and Horacio Vaggione.

\subsection{Jean-Claude Risset's 'exhaustive score'}

Risset had a specific idiom to refer to computer music code: 'exhaustive score', 'complete score' are recurrent in his writings. Before getting into detail, I would like to make a link with the scheme of Music N. In (Larrieu 2018: 70) I argue that the scheme is made of two parts, working together: on one hand, from top to bottom, there is the concept of orchestra, Ugen and parameters, and on the other hand, from top to bottom, the concept of score, instruments and notes. First, one have to notice that Jean-Claude Risset is a pioneer of computer music, before the democratisation of computer. Second, I note that the author is coherent with the Music N scheme, so that, as we will see, the understanding of this scheme permits us to shed light on the thinking of Risset.

Risset recurrently used the words 'exhaustive' and 'complete' to qualify the score of computer music. For example, in chronological order, I can cite:

The program [Music V] requires a 'score' which defines the desired sound: so this score is like a recipe to obtain the sound as well as an exhaustive description of the physical sound structure. [Le programme demande une « partition » qui lui spécifie le son voulu : cette partition est donc une recette d'obtention du son en même temps qu'une description exhaustive de sa structure physique]. Risset in (Lorrain 1980 : preface)

The programs giving the computer a synthesis recipe are the very scores of the sound structure, exhaustive and transmittable scores. [Les programmes stipulant à l'ordinateur la recette de synthèse sont de véritables partitions de la structure sonore, partitions exhaustives et transmissibles]. (Risset 1991)

A Music V score is, as well as a production recipe, a complete score : it represents the compositional elaboration of the sound microstructure. [Une partition Music 5, en même temps qu'une recette de production, est aussi une partition intégrale : elle représente l'élaboration compositionnelle de la microstructure du son] (Risset 2001).

I can understand those terms as an extension of the Music N scheme, where the Music N score (alphanumeric) is related to the traditional one (graphic). This is exactly what is done in (Mathews 1963: 554), where the conceptor of the language, Max Mathews, explains the scheme of Music N. And then, in the same way, while the traditional score needs a musician to be transformed into sound, the digital one does 
not require it. But, as a result, the digital score does need an abundance of details, 'processes are described almost atomic' Risset in (Lorrain 1980).

This last paragraph was useful to understand what Risset meant with these terms, but what is important in this article is the relationship the author enlightens between the digital score and sound. Indeed within a poietic view, one can easily see code as something powerful for studying the creative process, the composition, i.e. code as something resulting from a past process. But Risset invites us to see code also as something related to the sound heard: between code and sound there is a reciprocity. Indeed the reading of the former allows for a deeper listening of the latter. And this was already present in the introduction of the historic catalogue of Risset:

the computer data used for the synthesis of the sound affords a thorough description of the physical structure of these sounds (Risset 1969: 109).

Nearly half a century later, it can be said, more generally, that code and sound, or more precisely the computational process made by the composer and what we hear, are enriching each other.

\title{
3.2 Horacio Vaggione's 'direct writing'
}

I found this relation between code and sound in the writings of Horacio Vaggione, but in a different way. First, as I did with Jean-Claude Risset, I would like to make a link with the Music N scheme.

For Vaggione the note of the traditional musical theory, to which a graphic sign corresponds, is a 'syntactic brick' which is part of a 'reference level' (Vaggione 1998: 172). And, on each side of this level there are two domains, which are now well known :

- the macrotime level, above the note level, 'embracing all the possible scales going towards the "tall" ' (ibid.), my translation.

- the microtime level, below the note level, 'embracing all the possible scales going towards the "little" (ibid.), my translation.

In this respect, it goes without saying that Vaggione, unlike Risset, does not match with the Music N scheme. Indeed for Vaggione, musical score and notes cannot be assimilated to the score and note of Music N: the former are part of fixed operating level whereas the latter are not part of an operating level a priori :

\begin{abstract}
the denomination list of notes is nevertheless misleading because, even if it evokes some items 'list', those items do not correspond to the 'note' of the conventional notation, because here the item of the list can belong to any time level, and thereby can represent some duration belonging to the domain of microtime. (Vaggione 2010: 64), my translation.
\end{abstract}

The reciprocity between code and sound is not something which is at the centre of the thought of the author, it has not been substantially described. It is present as a key notion of the author, the one of object. One aspect of the notion is that object combines some sound and writing 'facts' : 
which time structures (some process, some morphologies) are determined not only as sonic facts but also, and indissolubly, as writing facts. [ [la notion d'Objet] ne correspond plus à l'entité purement macroscopique définie par Schaeffer (1966), mais sous-tend désormais un autre type d'entité composée dans laquelle des structures temporelles (des process, des morphologies) se trouvent déterminées non seulement en tant que faits sonores mais aussi, et indissolublement, en tant que faits d'écriture. (Vaggione 1998: 188).

And moreover, in the same text this 'double determination' leads the author to qualify the object as 'transparent', and also to put forward the idea of 'direct writing':

the digital sound object is transparent, that is to say it can be open in order to provide access to its internal structure, and therefore allow direct writing of the sound material itself. (Vaggione 1998: 192), my translation.

I also found this idea in the previous article, but only by an exogenously means, that is to say with some reflections on the historic work of Risset :

In fact, that is the study of a morphological salience [that of brass sounds] that led Risset [...] to state a model of dynamic character: an operative model, that you can translate in terms of parameters, thus inaugurating a 'direct writing' of the microtime phenomena forming part of the physical structure of sounds as well as of their perceptual identity. [En fait, c'est l'étude d'une saillance morphologique [celle des sons cuivrés] qui a conduit Risset $[. .$.$] à énoncer un modèle de ce caractère dynamique : un modèle$ opératoire, traduisible en termes paramétriques, inaugurant ainsi une "écriture directe" des phénomènes micro-temporels faisant partie de la structure physique des sons ainsi que de leur identité perceptive]. (Vaggione 2003: 92).

\subsubsection{Writing}

Through Risset and a fortiori Vaggione's writings, the specificity of computer music is now clear. The sound of this music is not evanescent, and cannot 'only be heard' as the one of acousmatic music. The sound of computer music can be enlightened with something that is written. Moreover, with Vaggione, this 'something else' of computer music - which is usually named code - is less understood as a 'new causality', or as a 'production process'. With (Zattra 2015), who speaks of 'text synthesis', and above all after reading Risset and Vaggione's writings, it can be seen that the specificity of computer music is well enlightened as far as writing is considered.

This feature can be surprising if I relate it with what is usually meant by 'music writing'. However it decreases if I compare two composition environments, the analog and the digital. In the former the composition is made with a mass of manipulations on electroacoustic devices, with some gestures, whereas in the latter, at the centre of the environment, there are two key devices: the screen and the alphanumeric keyboard.

In computer music the composition is made especially with a minimal unit, symbols, which lead, inevitably, to the idea of writing :

The computer has been to me the ideal tool because it brought the ability to work with discrete symbols on the level of the sound material and, 
consequently, to literally 'write' sounds. (Vaggione interviewed in Budón 2013: 102), my translation.

\section{ANALYSING COMPUTER MUSIC}

In the previous section I have enlighten the very spec-ificity of computer music when considering analysis: computer music is a written music. In this section I will now use this specificity to question computer music analysis. First, I will discuss the theories 'before the signal' previously mentioned, and second, I will dis-cuss of a recent analytical theory, the 'interactive aural analysis' conceived by Michael Clarke, which takes into account the written part of computer music.

\subsection{Faktura and genetic criticism applied to music}

Considering faktura first, since it is not dedicated to computer music, it does not take into account the specificity of computer music, the written code. Indeed, as we have seen, faktura can be applied to computer code as well as any electronic sound device used for composition.

By contrast, genetic criticism applied to music by Laura Zattra seems suitable. As we have seen, one key concept of the genetic criticism is writing, from which comes the original idea that 'synthesis data' can be seen as text. However, it has to be said that genetic criticism is fundamentally situated in the poietic: it did not take into account the sound actualisation of the musical work. As Zattra said, the goal of genetic criticism applied to computer music is to enlighten the 'forming process of the work' (Zattra 2015: 220). All the sounding and hearing aspect of those writings - which have been enlightened with Risset and Vaggione - are missing. One can say that genetic criticism applied to music is built on the idea that text is part of the genesis of the work, the creative process. If genetic criticism permits light to be shed on a musical work, it is thanks to its genesis. This focus on the creative process is for example present in a remark from Zattra on the work made by Lorrain on Inharmonique. To make his report, Lorrain rewrote the Music N score of Risset. In this operation, Zattra would appreciate 'a more precise explanation' of the 'interventions made on the original data' (ibid. 215), so that the reader could be as close as possible to the original 'text'. In this focus on the original text lies a second criticism I can make on genetic criticism applied to computer music. In my understanding the 'original text' is not essential, it is not 'the one' to absolutely get and study. One specificity of computer music is that, because of technology, one work can have many codes? ${ }^{7}$. It is not only because of the obsolescence of digital technology, but also because in computer programming you can obtained the same result in different way. Analysts and musicologists have to deal with that specificity. It is not because one work can have many code versions, in that studying all these versions and comparing them, is the only way to analyse the work. This does not mean that comparing different versions of one work is not interesting. It means that another way for analysing computer music could exist, going beyond all the versions of one work, not focusing on the differences which occur between versions and codes, but focusing on the work itself ${ }^{8}$.

7 One historic example is Stria (1977), with the original version and at least the two versions of (Dahan 2007) and (Baudoin 2007).

8 This point is truly important and must be developed in a substantial paper. At that time, one can think of the two concepts of early linguistic, synchrony and diachrony cf. (Saussure, 1969). 


\subsection{Between reading and listening}

Before concluding, I would like to present a recent analytical theory made by (Clarke 2012), which takes into account the written part of computer music. Michael Clarke's theory was made during an analysis of Mortuos Plango, Vivo Voco (1980) a tape for eight channels ${ }^{9}$, composed by Jonathan Harvey and assisted by Stanley Haynes. The article (Clarke 2005) is quite original because it is attached with a Max patch, which allows (i) to read the audio files of the work, (ii) to navigate within an aural pragmatic chart, and (iii) to compute some elements which enable to reproduce some extracts of the work.

The author has named his theory interactive aural analysis. But I am quite surprised with the term aural. Indeed, as we know, aural means that the analysis is based on hearing, that the only contact with the work is made through the ears. So, following my earlier diagram above, Clarke's theory is based on audio signal, on the listening of the signal. But, the computational elements present in his analysis testifies that his analysis is also made with an understanding 'before the signal' :

the software provides a series of interactive exercises illustrating the techniques used by Harvey in the work. In some cases synthesis is used to simulate the processes used by the composer. (Clarke 2006: 3)

Synthesis and sound processing are also used to illustrate some of the techniques used in the composition and the reader can experiment with modifying the parameters. (Clarke 2005: 115)

and more explicitly :

in this analysis detailed attention has been given in particular to the poietic element [...]. The composer also generously made his hand-written sketches available and these greatly aided the process of analysis. (Clarke 2006: 3)

In our context the analysis made by Clarke is quite particular because it seems that the author has not worked with the code of the work. The programmes used for composition were Music V and Chant cf. (Clarke 2005: 115, 117). Maybe, 26 years after the composition, these codes were no longer available. In this context, Clarke has simulated the transformations and synthesis made by the composer and his assistant in a more recent programming language, Max.

What I want to point out, despite the fact that the code of the work has not been used, is that Clarke's analysis is situated both 'before' and 'from' the signal. 'Before', because the analyst has used Max to simulate some extract of the work, and 'from' because the analysis contains an aural paradigmatic chart.

It is precisely in this combination of ways of making analyses that I found Clarke's theory interesting. If the author focuses on interactivity and the aural, I would like to focus on the fact that the analysis is made both by reading code - in Clarke's analysis the code was made by the author but one can think to a more recent work where all the code needed is available - and by listening to the music - by producing an audio paradigmatic chart.

9 Or should we say for the voice of a boy, bell rings and computer synthesis and treatments ? 
This way of analysing is the one that I argue in my PhD, (Larrieu 2018: 158). Since computer music is not a non-written music, the musicologist can both read and listen to the work. I support the idea of a circulation of meanings between the reading and the listening.

Thus, where we used to have only auditive feedback, we now have a confluence of the ears and eyes as well as the ability to store our actions in the form of codes. I think this is is a very positive aspect of computer music. (Vaggione interviewed in Budón 2013: 116)

With Vaggione, I understand that a theory for analysing computer music is relevant if it does allow a circulation of meanings, between what is read and what is heard.

\section{CONCLUSION}

In this article I have explored different theories for analysing computer music. In the first section I have made a diagram which organise some theories without ambiguity: analysis can be made before or from the signal of the work. Then I have explained two theories situated before the signal, the famous faktura by Battier, and the recent genetic criticism applied to music by Zattra. Even if the latter theories make a point such as (Menegheni 2007) - I feel they miss something which I find central to computer music, something which is related to the ontology of computer music works: they exist through writings, through what we used to call code. Tracing back the sparse history of computer music analysis, I have found in the second section that code was the object those theories do not apply to, because they did not manage to consider it. With the article (Stroppa 1984) used as a watermark, I have presented three points to illustrate this 'historical impermeability. In the third section I have considered 'the specificity of computer music', code as writing. The thinking of Risset and Vaggione helped me understand code not only as something coming from the poietic process, but also as something useful to understand music and sound. Finally, in the last section I have presented a recent theory by Clarke for analysing computer music, the Interactive Aural Analysis. Assuming the writing of computer music, I argue that this theory is relevant because it takes into account both the writing and the sounding part of computer music, even if it is not present in Clarke's demonstration.

I believe that if we understand computer music as a written one, it can open new directions for studying it. The work of Zattra, with genetic criticism, and of Clarke, with interactivity allowed with a Max patch, are two typical examples. However, to my knowledge, the writing of computer music hasn't been considered in a theory of analysis. One question which arises is: 'is a theory based on the writing of computer music relevant ?' For example, the Interactive Aural Analysis started with computer music (Clarke 2005), and a few years later the author expanded it to the acousmatic repertoire (Clarke 2009). Moreover, in a recent article, (Clarke 2012) writes 'it would be unfortunate to [...] restrict the interactive aural approach to the electroacoustic repertoire' suggesting that '[in] principle, the interactive aural analysis approach can be applied to any piece, though each new work will inevitably lead to extension and adaptation of the approach'. I would like to keep the question open, but I see one direction to go further: making some analysis of computer music works with high consideration to code as writing, and then thinking about how the knowledge inside 
code has enlightened the listening, and reciprocally. I think it should be possible to build some conceptual tools to facilitate and organise all the meanings which emerge in this kind of analysis.

\section{BIBLIOGRAPHY}

Battier, M. 2003. A Constructivist approach to the analysis of electronic music and audio art between instruments and faktura. Organised Sound 20(1): 60-67. DOI 10.1017/S1355771803000220

Baudoin, O. 2009. La faktura 'outil conceptuel d'analyse' - illustration avec Stria de John Chowning. Journées d'Informatique Musicale. Grenoble: JIM.

Bergsland, A. 2011. The six Fantasies Machine - an instrument modelling phrases from Paul Lansky’s Six Fantasies. New Interfaces for Musical Expression. Olso: NIME.

Bonardi, A. 2013. Pérenniser pour transmettre, transmettre pour pérenniser - Destins de l'oeuvre mixte interactive - autour de en Echo, pièce de Philippe Manoury. In Musique et technologie - Préserver, archiver, reproduire, Portraints Polychones, hors-série thématique. Paris, INA-GRM: 105-126.

Bonardi, A. 2017. Analyser l'orchestre électronique interactif dans les oeuvres de Manoury. In A. Bonardi, B. Bossis, P. Courpi, V. Tiffon (Eds.) Analyser la musique mixte. Sampzon: Delatour.

Budón, O. 2013. Composer avec des objets, réseaux et échelles temporelles: une interview avec Horacio Vaggione. In M. Solomos (eds.) Espaces composables. Essais sur la musique et sur la pensée musicale d'Horacio Vaggione. Paris: L'Harmattan.

Chion, M. 1994. Guide des Objets Sonores. Paris: Buchet Chastel.

Clarke, M. 2005. An interactive aural approach to the analysis of computer music. International Computer Music Conference. Barcelona: ICMC.

Clarke, M. 2006. Jonhatan Harvey’s Mortuos Plango, Vivo Voco. In M. Simoni (Eds.) Analytical methods of electroacoustic music. Abingdon: Routledge.

Clarke, M. 2009. Extending Interactive Aural Analysis : Acousmatic Music. Electroacoustic Music Studies Network. Buenos Aires: EMS.

Clarke, M. 2010. Wind Chimes and Interactive Aural Anlaysis. In Denis Smalley, Portraits Polychromes. Paris: INA-GRM.

Clarke, M. 2012. Analysing Electroacoustic Music : an Interactive Aural Approach. Music Analysis. 31(3): 347-380. doi 10.1111/j.14682249.2012.00339.x

Couprie, P. 2003. Analyse Comparée des Trois rêves d'oiseau de François Bayle. Démeter. Lille: Université de Lille 3. HAL hal-01257522

Couprie, P. 2016. Le développement d'un outil d'aide à l'analyse musicale : bilan et perspectives musicologiques. In Nicolas Marty (eds.) Musique électroacoustiques. Analyses - Écoutes. Sampzon, Delatour: 157-169.

Dahan, K. 2007. Reconstructing Stria. Proceeding of the 2007 International Computer Music Conference. Copenhagen: ICMC

Delalande, F. 2013. Analyser la musique, pourquoi, comment ?. Paris: INA-GRM.

Di Scipio, A. 2000. An analysis of Jean-Claude Risset's Contours. Journal of New Music Reseach 29 (1):1-21. doi 10.1076/0929-8215(200003)29:01;1-P;FT001

Donin, N. 2015. Introduction. In N. Donin, A. Grésillon, J-L. Lebrave (Eds.) Genèses Musicales. Paris: Presses Universitaire de Paris-Sorbonne. 
Dufeu, F. 2010. L’instrument numériqe comme objet d'analyse des musiques mixtes. Journées d'Informatique Musicale. Rennes: JIM

Emmerson, S., Landy, L. 2016. The analysis of electroacoustic music, the differing needs of its genres and categories. Proceeding of the 2012 International Computer Music Conference. Stockholm: ICMC

Forte, A. 1982. Introduction to schenkenrian analysis. New York: WW Norton Company.

Larrieu, M. 2018. Analyse des musiques d'informatique, vers une intégration de l'artefact.PhD, Université Paris-Est. HAL tel-01757277

Lerdahl, F., Jackendoff, R. 1983. A generative theory of tonal music. Cambridge, Massachusetts : MIT Press.

Licata, T. 2002. Electroacoustic music: Analytical perspectives. Westport, Connecticut: Greenwood Press.

Lorrain, D. 1980. Analyse de la bande magnétique de l’oeuvre de Jean-Claude Risset Inharmonique. Rapport Ircam 26/80.

Malloch, J., Birnbaum, D., Sinyor, E. 2006. Towards a new conceptual framework for digital musical instruments. Proceedings of the $9^{\text {th }}$ International Conference on Digital Audio Effects. Montreal: DAFx Conference.

Manning, P. 2004. Electronic and computer music. Oxford: Oxford University Press.

Marty, N. 2016. Introduction - Écoutes et analyses. In N. Marty (Eds.) Musiques électroacoustique - Analyses - Écoutes. Sampzon: Delatour.

Mathews, M. 1963. The digital computer as a musical instrument. Science. 142 (3592) : 553557

Meneghini, M. 2007. An analysis of the compositionnal techniques in John Chowning's Stria. Computer Music Journal 31(3): 26-37. DOI 10.1162/comj.2007.31.3.26

Mion P., Nattiez,J.J., Thomas, J.C., 1982. L'envers d'une oeuvre : "De natura sonorum" de Bernard Parmegiani. Paris : Buchet-Chastel.

Nattiez, J.J. 1987. Musicologie générale et sémiologie. Paris: Christian Bourgeois.

Nucibella, F., Porcelluzzi, S, Zattra, L. 2005. Computer Music Analysis via a Multidisciplinary Approach. Proceeding of the 2005 Sound and Music Computing. Salerno : SMS

Risset, J.C. 1969. An introducy catalogue of computer snthesized sounds. Murray Hill : Bell Telephone Laboraties.

Risset, J.C. 1991. Timbre et synthèse des sons. In J.B. Barrière (eds) Le timbre métaphore pour la composition. Paris: Christian Bourgois.

Risset, J. C. 2001. Problèmes posés par l'analyse d'oeuvres musicales dont la réalisation fait appel à l'informatique. Analyse et création musicales : actes du Troisième congrès européen d'Analyse Musicale (Montpellier, 1995). Paris: L'Harmattan, 131-159.

Ruwet, N. 1972. Langage, musique, poésie. Paris: Seuil.

Smalley D. 1986. Spectro-morphology and Structuring Processes. In: Emmerson S. (eds) The Language of Electroacoustic Music. London: Palgrave Macmillan.

Saussure, F. de. 1969. Cours de linguistique générale. Paris: Payot.

Schaeffer, P. 1952. À la recherche d'une musique concrète. Paris: Edition du Seuil.

Stroppa, M. 1984. The analysis of electronic music. Contemporary Music Review 1(1): 175180. doi 10.1080/07494468400640161

Thomas, J. C., Mion, P., Nattiez, J. J. 1982. L'envers d'une oeuvre : “De natura sonorum” de Bernard Parmegiani. Paris: Buste-Chastel. 
Vaggione, H. 1998. Son, temps, objet, synthaxe. Vers une approche multi-échelle dans la composition assistée par ordinateur. In A. Soulez and H. Vaggione (eds.) Cahiers de Philosophie du Langage, number 3 (Musique, rationalité, langage. L’harmonie : du monde au matériau). Paris : L’Harmatan, 169-202.

Vaggione, H. 2003. Composition musicale et moyens informatiques : questions d'approche. In A. Soulez and et M. Solomos (eds.) Formel, informer : musique-philosophie. Paris : L'Harmattan, 91-116.

Vaggione, H. 2010. Représentations musicales numériques : temporalités, objets, contextes. In A. Soulez and H. Vaggione (eds.) Manières de faire des sons. Paris : L’Harmattan, 155174.

Wang, G. 2008. The Chuck audio programming language. 'A string-timed and on-the-fly environ/mentality. PhD, Princeton University.

Zattra, L. 2005. Analysis and analyses of ecltroacoustic music. Proceeding of the Sound and Music Computing, vol 36. Salerno (Italy) : SMC Network.

Zattra, L. 2015. Génétiques de la computer music. In N. Donin, A. Grésillon, J.L. Lebrave (eds.) Genèses musicales. Paris : Presses Universitaires de Paris-Sorbonne. 